\title{
The Clay Ball Site in the Upper Neches River Basin of East Texas
}

Timothy K. Perttula

Heritage Research Center, Stephen F. Austin State University

Bo Nelson

Heritage Research Center, Stephen F. Austin State University

Follow this and additional works at: https://scholarworks.sfasu.edu/ita

Part of the American Material Culture Commons, Archaeological Anthropology Commons, Environmental Studies Commons, Other American Studies Commons, Other Arts and Humanities Commons, Other History of Art, Architecture, and Archaeology Commons, and the United States History Commons

Tell us how this article helped you.

This Article is brought to you for free and open access by the Center for Regional Heritage Research at SFA ScholarWorks. It has been accepted for inclusion in Index of Texas Archaeology: Open Access Gray Literature from the Lone Star State by an authorized editor of SFA ScholarWorks. For more information, please contact cdsscholarworks@sfasu.edu. 


\section{The Clay Ball Site in the Upper Neches River Basin of East Texas}

Creative Commons License

(c) (i) (8)

This work is licensed under a Creative Commons Attribution-NonCommercial 4.0 International License 


\title{
The Clay Ball Site in the Upper Neches River Basin of East Texas
}

\author{
Timothy K. Perttula and Bo Nelson
}

\section{INTRODUCTION}

The Clay Ball site is an ancestral Caddo site believed to be located in the upper Neches River basin in East Texas. The site is notable for its series of small, square vessels with Frankston phase (ca. A.D. 14001650) engraved motifs, as such vessel forms have not been previously documented in studies of Frankston or later Allen phase (ca. A.D. 1650-1830) vessel assemblages.

The unique ceramic vessels from the site were excavated by Buddy C. Jones, and although his main site collecting and excavation work was in the mid-Sabine River basin (Jones 1968), he did excavate several sites in the upper Neches River basin in Anderson, Cherokee, and Smith counties (see Perttula 2011a; Perttula and Nelson 2013a, 2013b; Perttula et al. 2013). Unfortunately, Jones left no notes or records associated with the Clay Ball site that would allow us to either ascertain the contextual relationship of the various features at the site where they were excavated, nor for that matter even provide a locational description of the site.

\section{VESSEL DESCRIPTIONS}

The Clay Ball site vessel assemblage includes one jar, six square bowls, two bowls, a globular carinated bowl, and an effigy bowl. All are grog-tempered.

The jar (2003.08.929) stands $22.5 \mathrm{~cm}$ in height, and has an orifice diameter of $18.0 \mathrm{~cm}$. The rim and body have vertical brushing marks, and there are two sets of two appliqued lugs on the rim (Figure 1).

The square bowls are between $4-5 \mathrm{~cm}$ in height, and have distinctive engraved motifs on their four sides. One (2003.08.3166) has a series of nested engraved rectangles (Figures 2 and 3a), while a second (2003.08.3165) has panels with either central circles and radiating engraved lines (Figures $3 e$ and $4 a$ ) - reminiscent of varieties $J-L$ of Poynor Engraved in the upper Neches River basin (Perttula 2011b:Figure 6-65) - or concentric open and hatched ovals (Figures 3e' and 4b; cf. varieties $S$ and $S^{\prime}$ of Poynor Engraved in the upper Neches) - on all four sides of the panel.

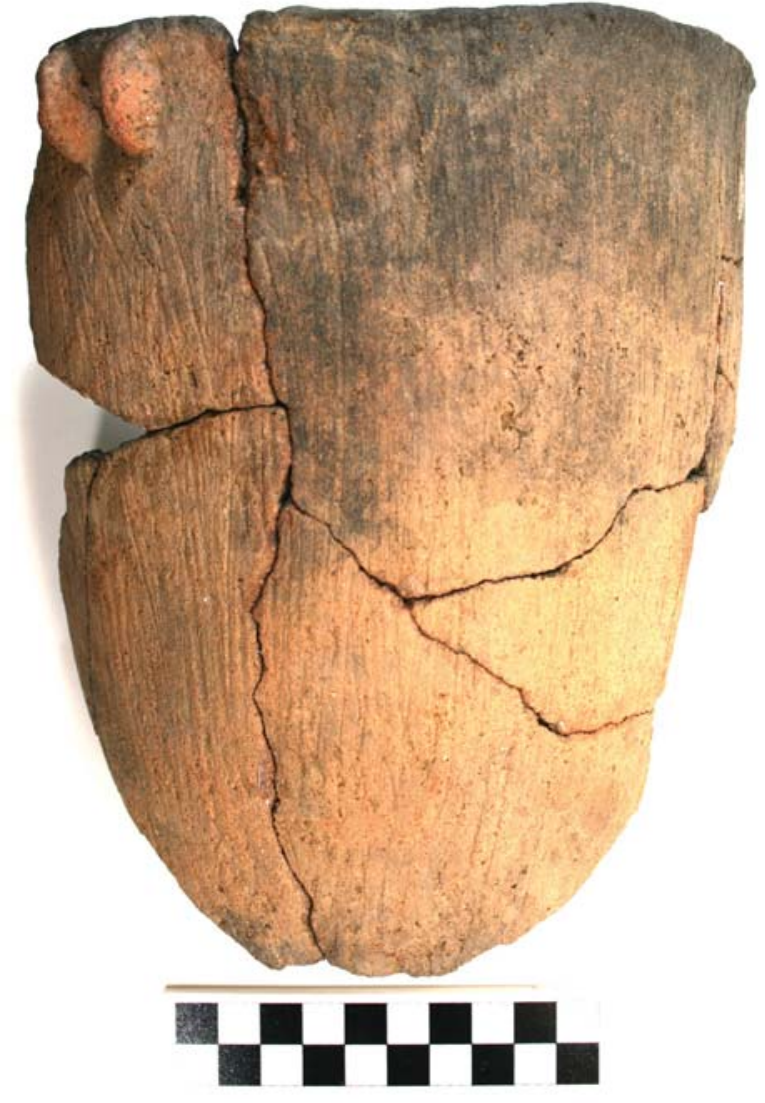

Figure 1. Brushed-appliqued jar from the Clay Ball site. 

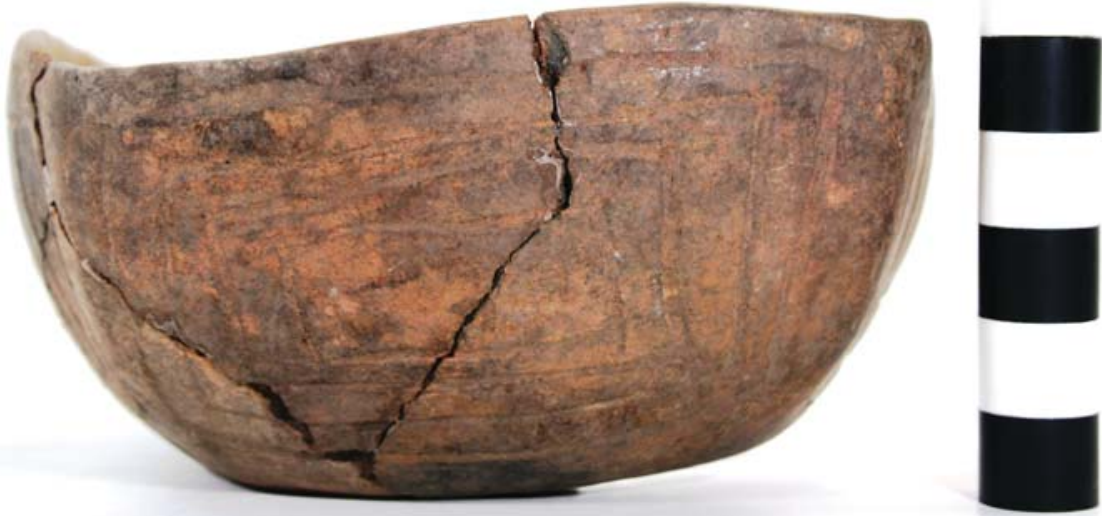

Figure 2. Square bowl with engraved nested rectangles, Clay Ball site.

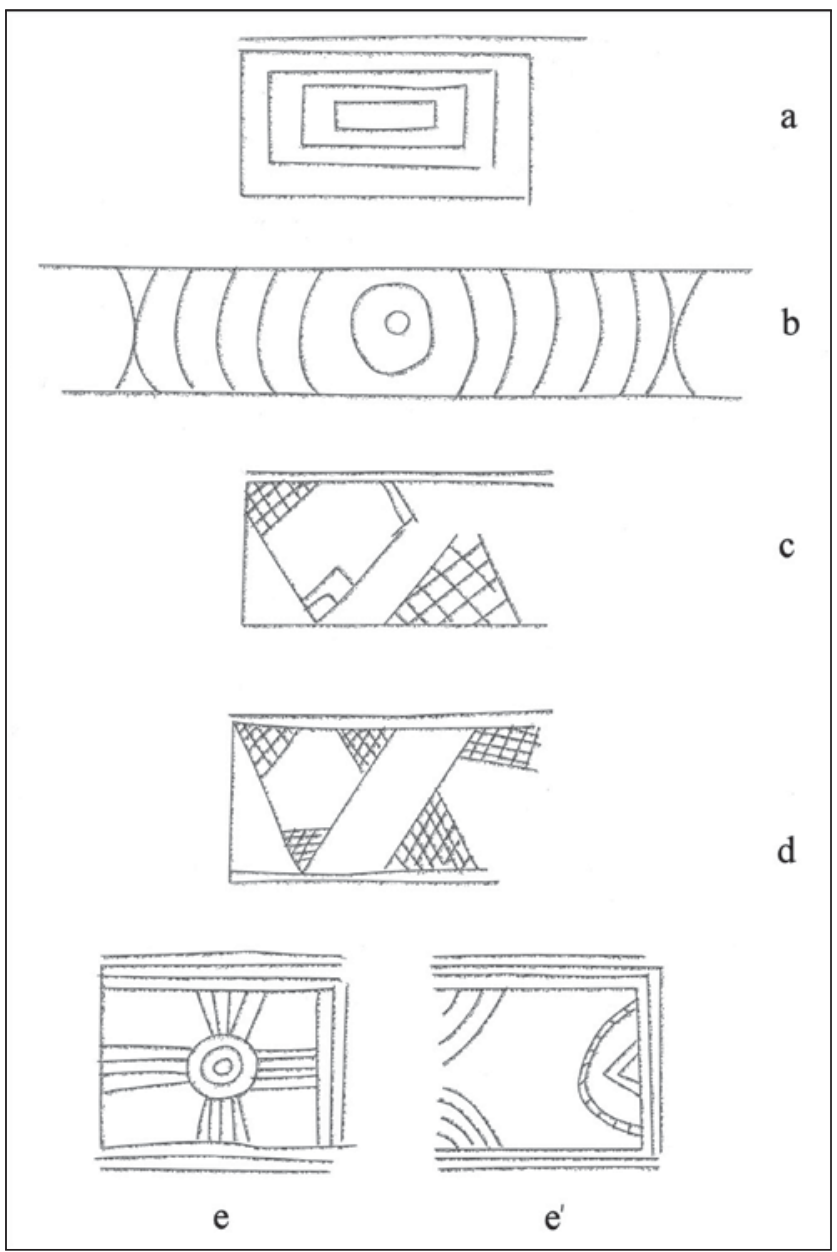

Figure 3. Drawings of engraved motifs on square bowls from the Clay Ball site: a, engraved rectangles; $b$, engraved motif on effigy bowl; c-d, engraved triangle motifs; e, circles and ovals. 

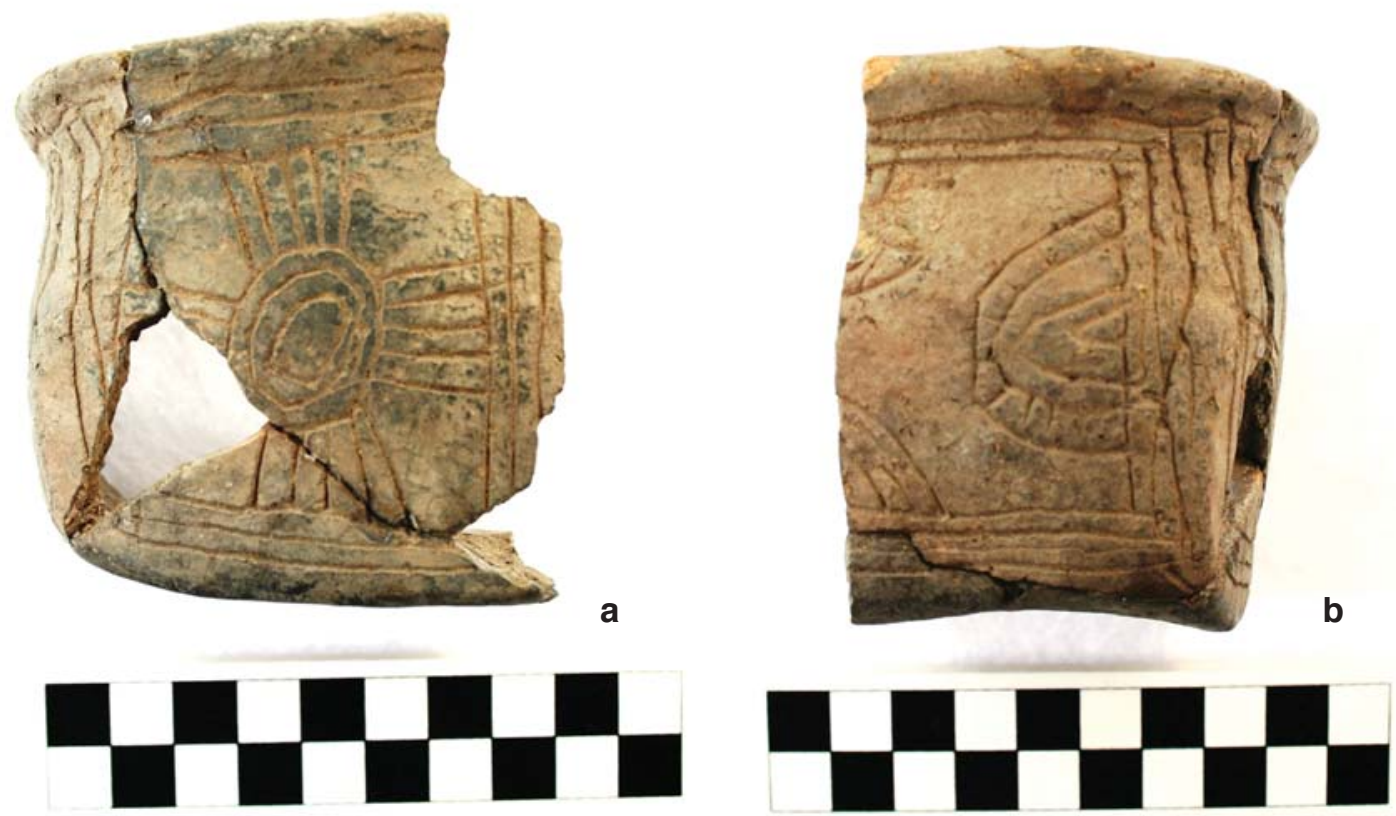

Figure 4. Square bowl from the Clay Ball site: a, panels with central circles; b, panels with concentric and hatched ovals.

Three other square bowls (2003.08.3163, 2003.08.3164, and 2003.08.3170) have large engraved triangle motifs (Figures 5-7), with two triangles per motif, each with its apex pointing either at the vessel rim or the base. This motif resembles Var. M of Poynor Engraved (Perttula 2011b:Figure 6-65). On two of the vessels, the triangles have cross-hatched corners (see Figures 3c-d and 5-6), while on the third (Figures 7 and 8b), the corners have curvilinear hatched lines, creating a nested oval within the triangles. Var. F of Poynor Engraved in the upper Neches River basin has such nested ovals within large triangles (Perttula 2011b:Figure 6-65).
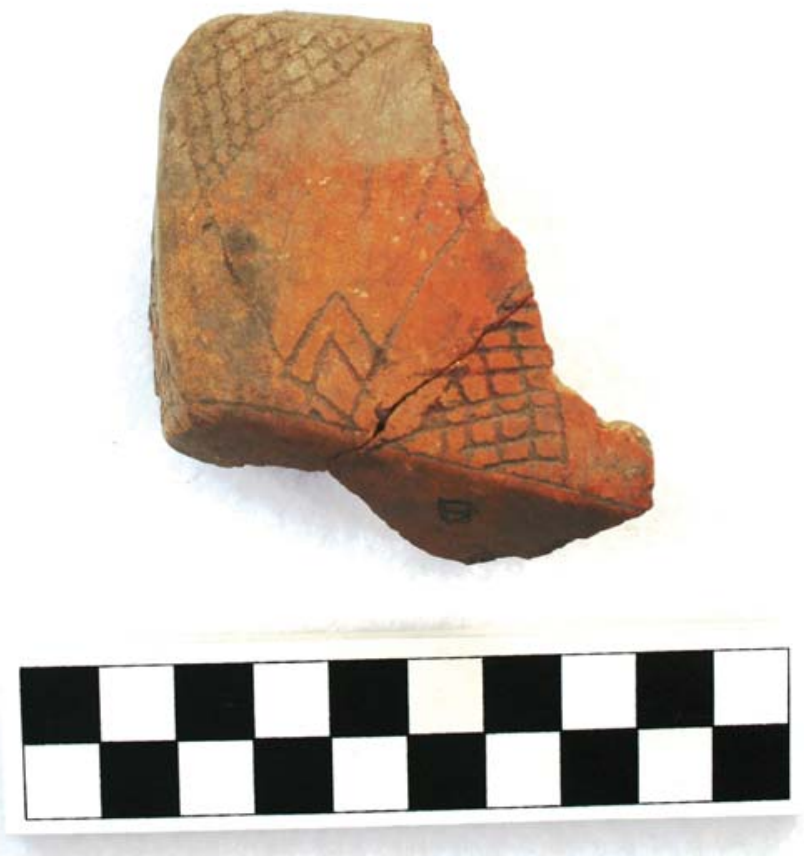

Figure 5. Square bowl (2003.08.3163) from the Clay Ball site. 

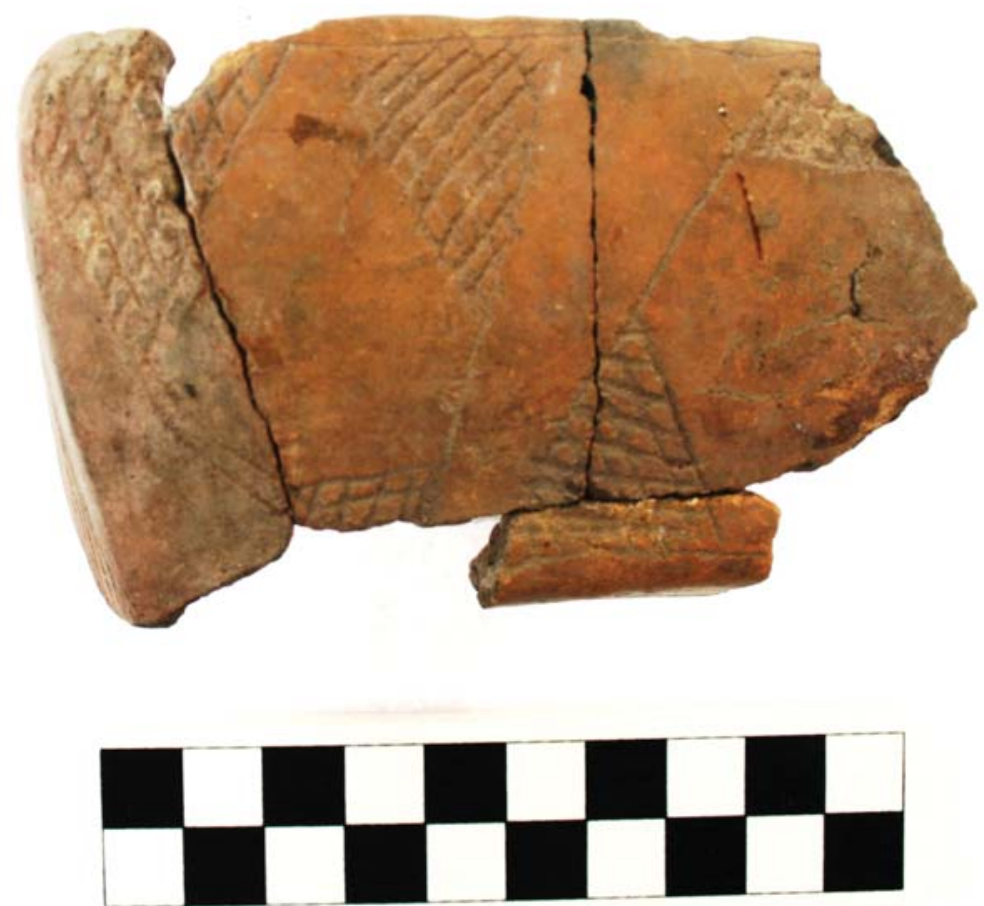

Figure 6. Square bowl (2003.08.3164) from the Clay Ball site.
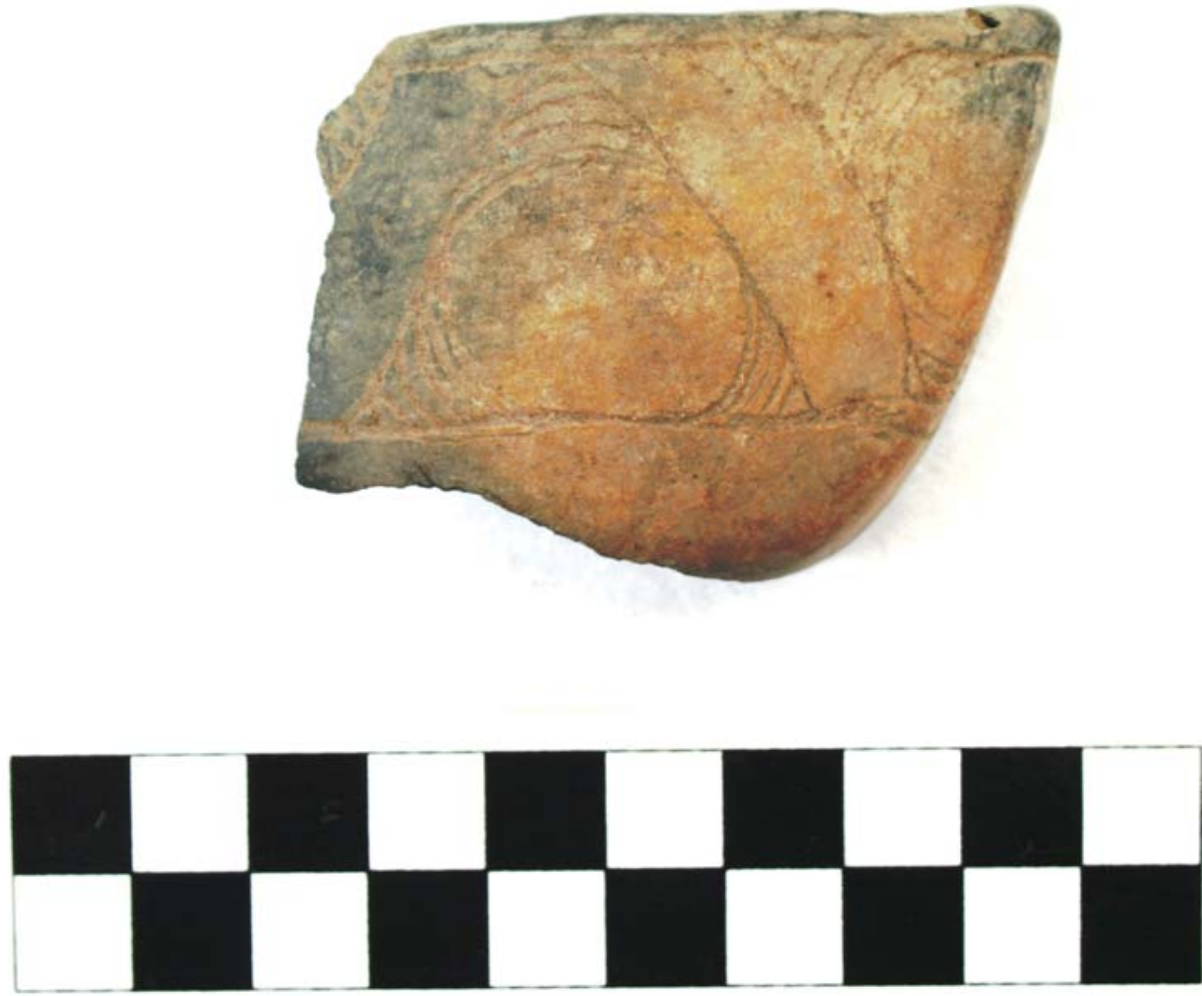

Figure 7. Square bowl (2003.08.3170) from the Clay Ball site. 


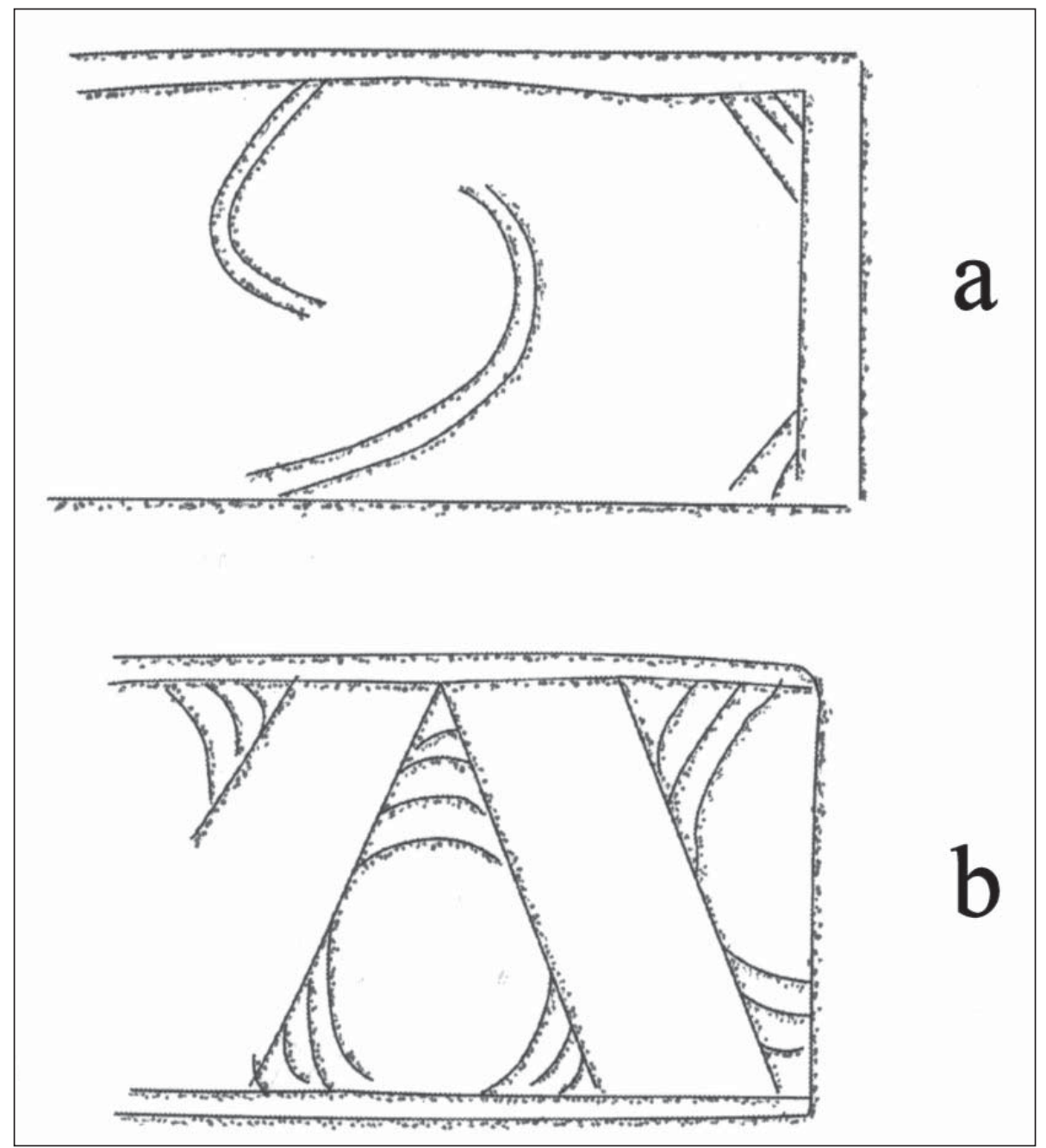

Figure 8. Drawings of engraved motifs on square bowls from the Clay Ball site: $a$, hooked arm element; $b$, nested ovals within engraved triangles.

The last of the square bowls (2003.08.3169) has panels on each side with centrally placed hooked arm elements (Figures 8a and 9). Vars. N, P, and P' of Poynor Engraved have hooked arm elements, either open or hatched hooked arms (Perttula 2011b:Figure 6-65).

The first of the bowls is plain (2003.08.3167). It has a $20.0 \mathrm{~cm}$ orifice diameter (Figure 10). The second is a shallow and elongated bowl (2003.08.3162), and may have been canoe-shaped (Figure 11). Such vessels have been described in vessel collections from the region, but are not well documented. This vessel is decorated on its sides with a continuous series of vertical to near-vertical engraved lines.

The carinated bowl (2003.08.3161) has a globular body, which is a common form for upper Neches River basin vessels of Late Caddo period age (see Perttula 2011b:Figure 6-27f). The vessel is $9.5 \mathrm{~cm}$ in height, and has a $15.8 \mathrm{~cm}$ orifice diameter; its volume is estimated at 0.9 liters. The rim is divided into oval-shaped panels by excised brackets. Every other panel has a central engraved circle (Figure 12). The decorative motif shares elements with both Poynor Engraved, var. Hood and var. Lang (Perttula 2011b:Figure 6-64e-f). 

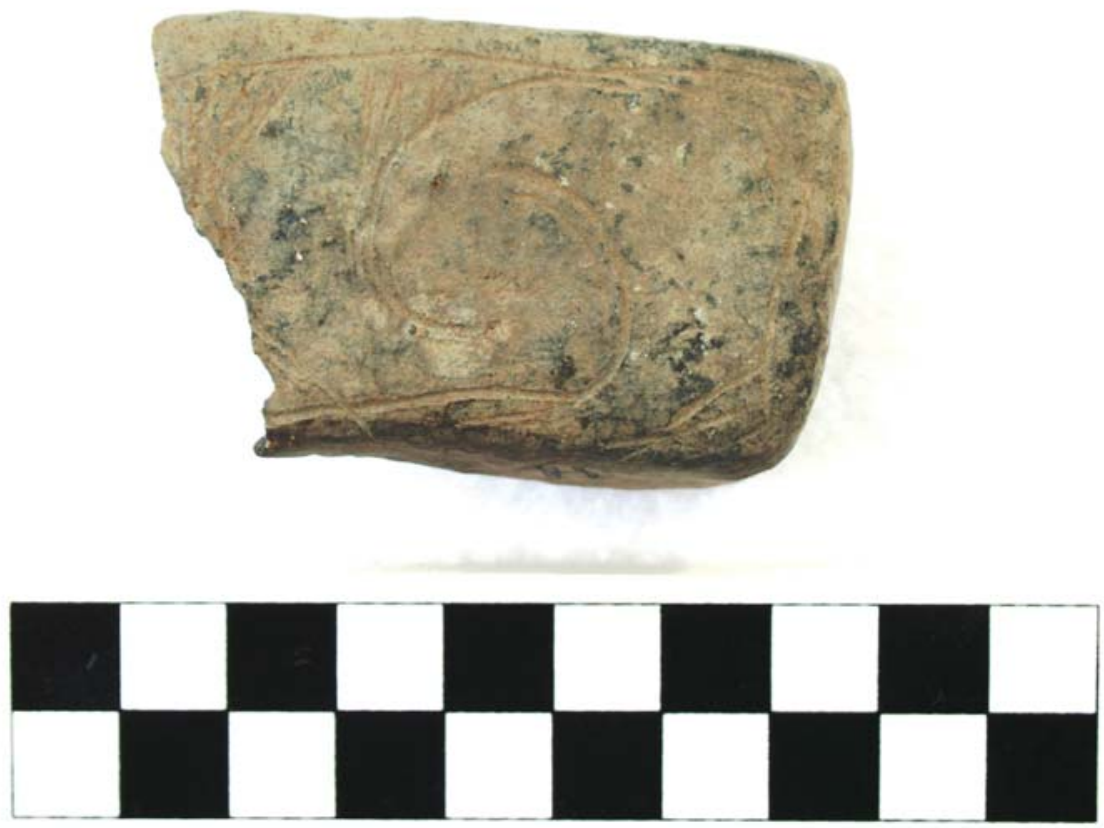

Figure 9. Square bowl (2003.08.3169) from the Clay Ball site.

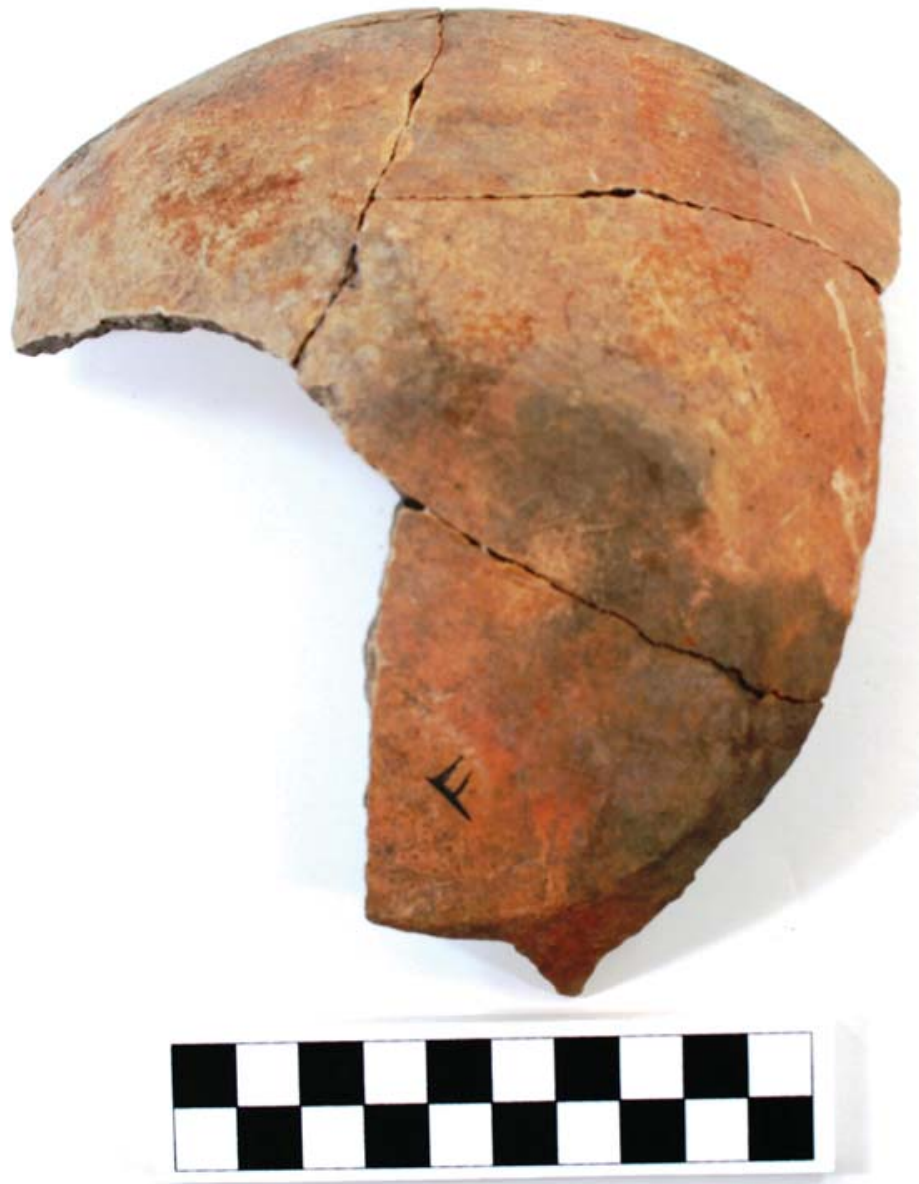

Figure 10. Plain bowl from the Clay Ball site. 

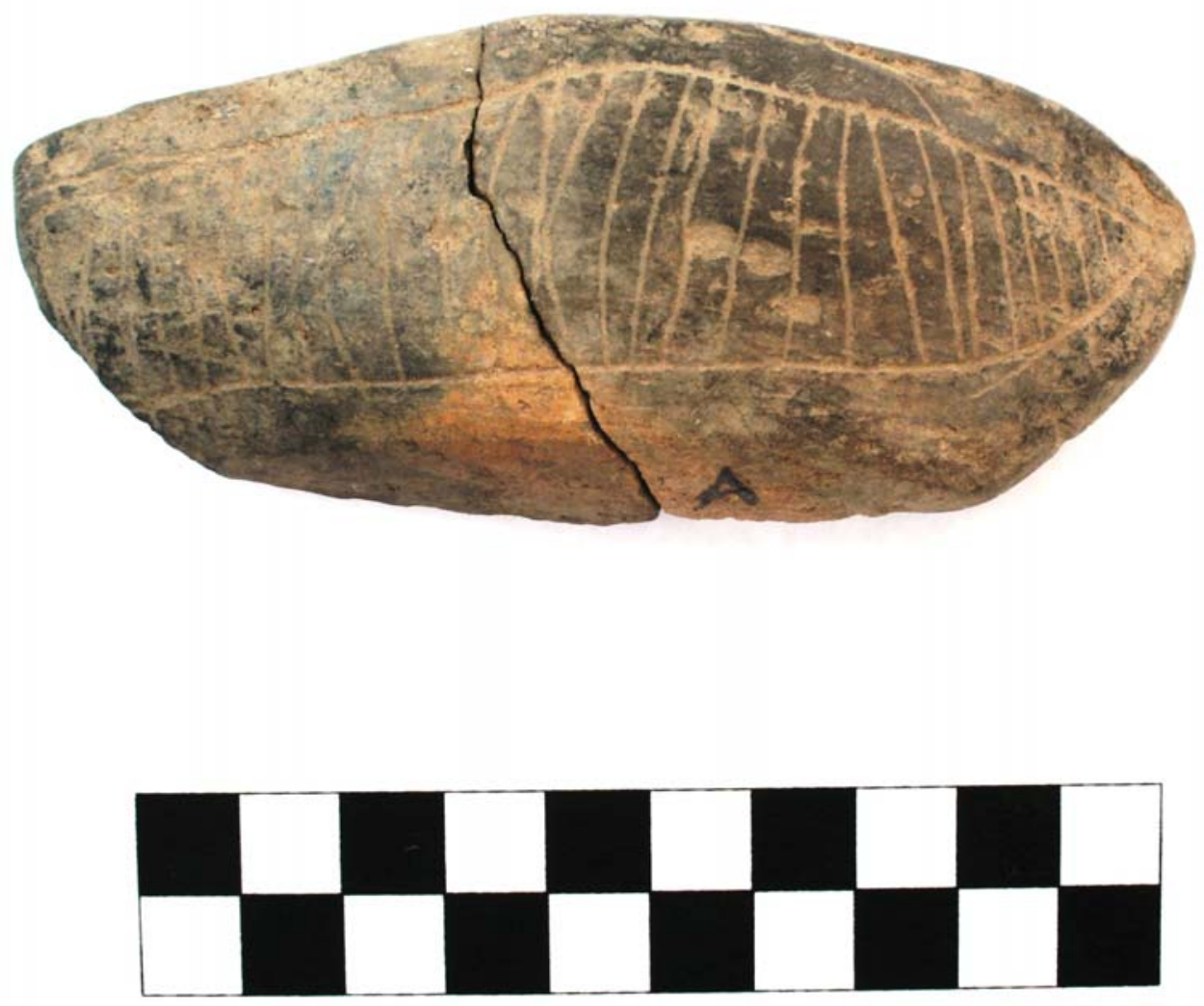

Figure 11. Engraved bowl from the Clay Ball site.

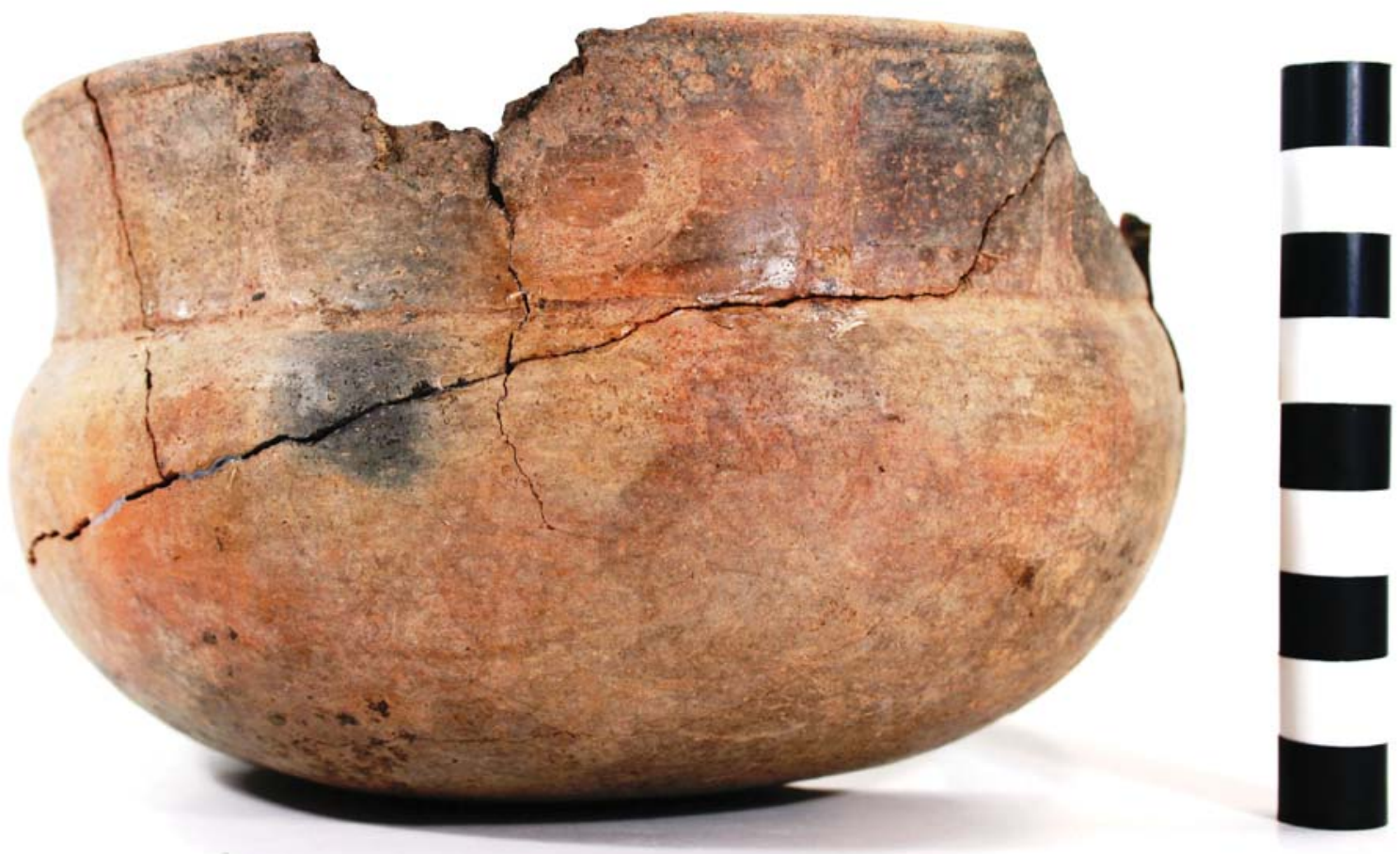

Figure 12. Poynor Engraved carinated bowl from the Clay Ball site. 
The effigy bowl (2003.08.3168; $8.2 \mathrm{~cm}$ in height and $16.5 \mathrm{~cm}$ orifice diameter) has an applied bird or duck head and a tab tail that supported a tail rider; the tail rider has become detached from the vessel lip. Vessels with effigy heads and tab tails in the upper Neches River basin have been classified as Hood Engraved, var. Allen (Perttula 2011b:271), but the decoration on these vessels has only broad horizontal engraved lines. The Clay Ball effigy bowl has an engraved concentric circle and arcing lines motif repeated on either side of the bowl, and the motifs are divided by two sets of engraved brackets; the brackets have been placed on the bowl under the effigy and tab tail (Figure 13; see also Figure 3b). A red clay pigment has been rubbed in the engraved lines.

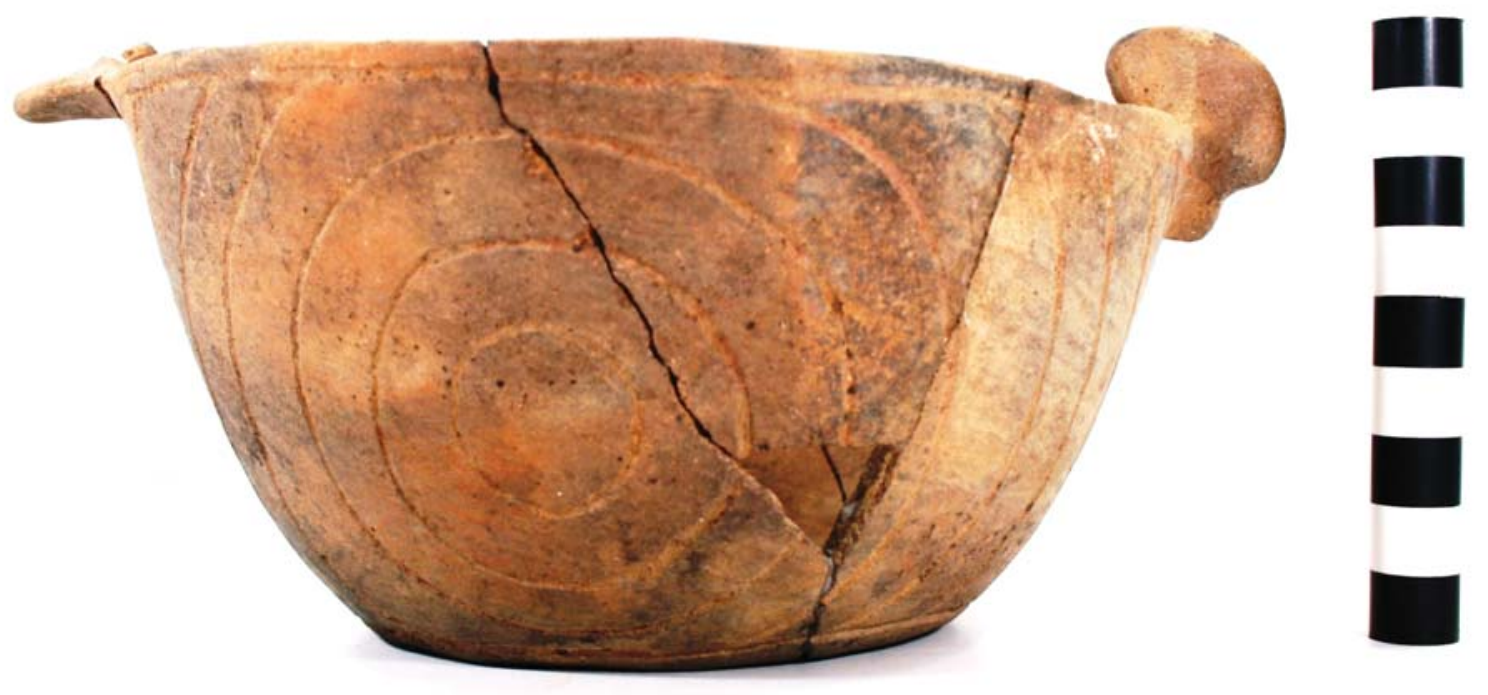

Figure 13. Hood Engraved effigy bowl from the Clay Ball site.

\section{SUMMARY AND CONCLUSIONS}

The Clay Ball site is distinctive because of the number of small square engraved bowls that have been found there in excavations by Buddy Jones. These bowls have ancestral Caddo Frankston phase engraved motifs that have been identified in the upper Neches River basin (cf. Perttula 2011b), and this is the most plausible regional location of the site.

These small square bowls are a unique vessel form that has not been previously documented in the region, but the motifs found on them are useful in establishing their temporal and spatial context, especially given the absence of site provenience information provided by Jones. The motifs on these square bowls and the one globular carinated bowl resemble a number of regional varieties of Poynor Engraved defined in the upper Neches River basin (Perttula 2011b:Figures 6-4 and 6-65). These are varieties with less common rim motifs currently known at only a few sites:

These varieties feature a diverse range and combination of stylistic elements, principal among them nested triangles, nested ovals, and nested circles; scrolls of various sorts; hatched pendant, stacked, and nested triangles; cross-hatched ladders and panels; hooked arms; concentric ovals; and sets of diagonal lines with small pendant triangles (Perttula 2011b:268).

The seriation of Poynor Engraved varieties in the upper Neches River basin suggests that the square bowls from the Clay Ball site most likely are from burials that date from subphases 1 and 2 of the Frankston phase, namely A.D. 1400-1560 (Perttula 2011b:Table 6-37). The one globular carinated bowl has a Poynor 
Engraved motif that shares elements of both var. Hood and var. Lang. These varieties are most common in subphase 2 of the Frankston phase, estimated to date from A.D. 1480-1560. The hooked arm motif on the one square bowl is rare on Poynor Engraved vessels in the upper Neches River basin, but such motifs occur only in subphase 3 of the Frankston phase, dated between A.D. 1560-1650.

\section{ACKNOWLEDGMENTS}

Thanks to Patti Haskins of the Gregg County Historical Museum in Longview, Texas, who brought this collection to our attention, and facilitated its documentation. Lance Trask prepared the vessel motif drawings.

\section{REFERENCES CITED}

Perttula, T. K.

2011a The Pipe Site, a Late Caddo Site at Lake Palestine in Anderson County, Texas. Journal of Northeast Texas Archaeology 35:47-80.

2011b The Ceramic Artifacts from the Lang Pasture Site (41AN38) and the Place of the Site within an Upper Neches River Basin Caddo Ceramic Tradition. In Archeological Investigations at the Lang Pasture Site (41AN38) in the Upper Neches River Basin of East Texas, assembled and edited by T. K. Perttula, D. B. Kelley, and R. A. Ricklis pp. 145-320. Archeological Studies Program report No. 129. Texas Department of Transportation, Environmental Affairs Division, Austin.

Perttula, T. K. and B. Nelson

2013a The Mud Creek Site in the Angelina River Basin, Cherokee County, Texas. Journal of Northeast Texas Archaeology 41:31-39.

2013b A Frankston Phase Settlement and Cemetery at the H. C. Slider Site on the Neches River in Cherokee County, Texas. Journal of Northeast Texas Archaeology 41:41-56.

Perttula, T. K., B. Nelson, and R. Z. Selden, Jr.

2013 Documentation of Cemeteries and Funerary Offerings from Sites in the Upper Neches River Basin, Anderson, Cherokee, and Smith Counties, Texas. Special Publication No. 26. Friends of Northeast Texas Archaeology, Pittsburg and Austin. 